\title{
CONSIDERING POLITICAL ALTERNATIVES TO "HARD LOOK" REVIEW
}

\author{
Peter L. Strauss*
}

That is absolutely right. I am sufficiently confused by the facts that are already on the table - two of them in particular. One (the dog that I thought was barking im that interestimg first chart Don Elliott put up, on which he did not remark), is that the first two periods of judicial review he showed us had 337 and 294 cases of judicial review each; for the third period, for the same length of time, the figure is about $800 .{ }^{1}$ Something is going on there. The other is just a square conflict that our moderator is much better positioned than I am to tell us about. He recently published a fascimating study in the Duke Law Journal that purports to show that the affirmance rate for administrative agencies in the D.C. Circuit, which gets about $60 \%$ of admimistrative appeals these days, is only $30 \% .^{2}$ His figures are from 1987, not 1984 or 1985, but I doubt court performance has changed so sharply in such a very short period of time. These facts warrant some further exploration.

Cass Sunstein and Don Elliott each, in his way, was talking about the results of mdividual cases and the implications for individual cases of htigation or hitigation outcomes. I might describe this as the micro-perspective on judicial review and its impact. I will be speaking at a different level of abstraction-without facts, of course-but at a level that seems an important one. My remarks are generally addressed to the macro-perspective, to examining the overall, systemic impact of judicial review of a certain intensity on the way agencies go about their business. This is rather like the Mashaw-Harfst study to which you have already heard Cass Sunstein refer, a good portion of which appeared over a year ago in the Yale Journal on Regulation, ${ }^{3}$ and that will eventually appear as a book from Harvard University Press. It is a wonderful study. Rather like Shep Melmick's study ${ }^{4}$ and some others, it tells a cautionary

* Betts Professor of Law, Columbia University School of Law.

1. See Shuck \& Elliott, To The Chevron Station: An Empirical Study of Federal Administrative Law, 1990 DUKE L.J. (forthcoming).

2. Pierce, Two Problems in Administrative Law: Political Polarity on the District of Columbia Circuit and Judicial Deterrence of Agency Rulemaking, 1988 DuxE L.J. 300, 305.

3. Mashaw \& Harfst, Regulation and Legal Culture: The Case of Motor Velicle Safety, 4 YALE J. ON REG. 257 (1987).

4. R. Melnick, Regulation and the Courts: The Case of the Clean air Act (1983). 
tale about the systemic impact of judicial review on the costs of agency behavior.

What I want to do at the outset is ask you to imagine the situation facing George Bush as he assumes the Presidency. And it would have been the same for Michael Dukakis. However much regulation the President means to accoinphish over the next four or eight years, the one thing he knows is that, for his administration, he has to accomplish that much regulation for fewer dollars. This is another side, if you hike, a narrower side of the efficiency constraint that Cass was talking about, that government has got to get imto a leaner posture. If, as Jerry Mashaw and others seem to be telling us, one impact of intensive judicial review is that it leads agencies to spend more money on a particular regulatory enterprise and, consequently, to have fewer enterprises that they can take on as a whole, that might be regarded as a negative impact by anyone who thought that regulation was an appropriate part of the picture. If, unlike Cass but like some of his Chicago colleagues, you thought that the only good regulator was a dead regulator, this particular impact would not especially trouble you; but if you had a regulatory program, it would trouble you. This seems to me to put a comparative cast on the question before us. Close judicial scrutiny as compared to what? What things can the courts do as compared to those things that perhaps Congress or the President can do?

And now with that very general effort to relate what I am about to say to what the two previous speakers have said, I will dive into my prepared remarks, lose eye contact with you and all the rest of that.

At one level, I thought I knew what this question was about when Dick sent it to me, and how it presented itself to you. The issue to be discussed today was whether we were for or against the Supreme Court's decision in Motor Vehicles Manufacturers Association v. State Farm Mutual Automobile Insurance Co., in which the Court essentially endorsed "hard look" review.5 Those who are for it believe William Pedersen's testimony some years ago, as a high level official of the EPA, that the judicial process is the ouly process past the staff level in an administrative agency that is likely to produce any significant level of factual probing, and that the inquiry imto "the minute details of methodology, data sufficiency and test procedure" gives those inside the agency, "who care about well-documented and well-reasoned decisionmaking a lever with which to move those [inside the agency] who do not."6 They believe on the whole that is a good thing. Richard Stewart is on record expressing

5. 463 U.S. 29 (1983).

6. Pedersen, Formal Records and Informal Rulemaking, 85 YALE L.J. 38, 60 (1975). 
similar views. ${ }^{7}$

Those who are against hard look review believe with Steven Breyer ${ }^{8}$ that it calls on judges to perform a function for which they are not wellsuited; or with Martin Shapiro, that review's inevitable tendency to focus on only a limited number of issues in a coinplex proceeding invites a distortion of agency effort and a quite imperfect view of agency process; ${ }^{9}$ or with Shep Melnick, that the programinatic impact on the agency of hard look review is at best mixed and probably productive of misallocated resources-too much tiine spent on too few rules, excessive effort in a few instances producing under-regulation (that is, the absence of funds to make any effort) in others. ${ }^{10}$ Whatever OSHA may have accomplished by the rules that it has adopted, all of us know the stories of the many rules that it has not adopted. ${ }^{11}$ This was certainly a sentiment I often heard expressed by the rulemakers of the Nuclear Regulatory Coininission when I was there. Hard look review meant more work for them but no significant change in regulatory outcomes in particular cases-just fewer rules with the resources that were available to them to make rules. Again, you can approve of that as an outcoine, but it is not necessarily what Congress would have chosen.

The challenge we have been given, however, is not nearly so limited as that. As Cass addressed it, it is whether close judicial scrutiny of agency action produces net benefit or net detriment generally. So stated, the question is not limited to rulemaking and is not limited to close scrutiny of factual or judgmental elements of the agency's action, as the hard look notion is; nor is it limited, as I think that narrower topic also is, to imagiming that the net beneficiaries or sufferers as a result of close judicial scrutiny are us-that is to say, the general public whose good is sup-

7. See Stewart, The Development of Administrative and Quasi-Constitutional Law in Judicial Review of Environmental Decisionmaking: Lessons from the Clean Air Act, 62 IowA L. REv. 713, 763 (1977). (1986).

8. See Breyer, Judicial Review of Questions of Law and Policy, 38 ADMIN. L. REv. 363, 388-94

9. M. SHAPIRo, Who GUARDS THE GUARDIANS? Judicial CONTROL of ADMINISTRATION 151-56 (1988); see also Vermont Yankee Nuclear Power Corp. v. NRDC, 435 U.S. 519 (1978).

10. See R. MELNICK, supra note 4, at 361-73.

11. OSHA recently imposed new limits on 376 different substances found in the workplace, a result of proceedings that, given the broad sweep of the regulations, were cursory in comparison with earlier efforts. Occupational Health and Safety Standards on Air Contaminants, 54 Fed. Reg. 2332 (1989) (to be codified at 29 C.F.R. $\S 1910.1000$ ). The rules relied extensively on improved consensus standards generated by private standard-setters, particularly the American Conference of Governmental Industrial Hygienists, in the seventeen years since adoption of the original standards. During those 17 years, OSHA adopted regulations controlling only 24 substances. See Molotsky, New Limits Imposed on 376 Substances Found in Workplace, N.Y. Times, Jan. 14, 1989, at 1, col. 1, 6, cols. 5 6; cf. Michaelson, Atmospheric Pressure: Work-Safety Agency Tries a Squeeze Play, Legal Times, Oct. 24, 1988, at 33, col. 1 . 
posed to be the end generally of the legal order. We could be talking about close scrutiny of adjudication results, of adıninistrative assessments of questions of constitutionality or law, and we could be asking the question from the perspective of a regulatory subject seeking review, not from the perspective of the broadly interested public.

In that respect, Don Elliott's closing comments are quite right. I well remeinber a conversation I had with a former Supreme Court law clerk, then in private practice, when I was an attorney in the Solicitor General's office. He had filed a jurisdictional statement in a case to which it had fallen on me to write the response. The case was devoid of merit; there was not one chance in 50,000 that the Court would be interested in it. Fate threw us together at a party, and I asked him why he had imposed on the Court's time this way. "Well," he said "the license is worth $\$ 90,000$ a day for the client." For the client, that was sufficient justification to seek any kind of look.

That it seems so natural to state and understand the question put to us in the inore limited way is just one more ineasure of what Cass Sunstein recently pointed out in the pages of my home town law reviewthat in the past two decades we have seen a striking shift from private law to public law thinking about administrative law in general, and about judicial review in particular. ${ }^{12}$ Twenty years ago it would have been clear that the question before us was one about whether the particular individuals seeking review were entitled to close judicial scrutiny or not. And, on the whole, those seeking review would not have included the persons whom the regulatory scheme was intended to protect. The interests of regulatory beneficiaries would have been thought to lie against review rather than for it, because review inhibits sturdy and swift governmental attempts to control anti-social behavior by regulation. ${ }^{13}$ The argument for review would have been framed in terms of right, not in terms of net benefit-review as a means of securing the protection of individual liberty, not as an element of assuring effective social program implemnentation. "The availability of judicial review," Louis Jaffe then wrote, "is the necessary condition, psychologically if not logically, of a system of admimistrative power which purports to be legitinate, or legally valid." 14 Wise as it is, that statement is one whose presupposition is "as against the citizens on whom the system of administrative power will

12. See Sunstein, Standing and the Privatization of Public Law, 88 Colum. L. Rev. 1432, 143233 (1988).

13. A classic statement of the position may be found in Justice Fortas's dissent in Toilet Goods Ass'n v. Gardner, 387 U.S. 167, 198 (1967) ("The overriding fact here is-or should be-that the public interest in avoiding the delay in implementing Congress' program far outweighs the private interest ....").

14. L. JAFFe, Judicial Control of Administrative Action 320 (1965). 
do its work." It does not ask, as I think we do today, whether judicial review will help the system do its work better, or what its programmatic impact is-its capacity to produce behavior by governmental officials in cases in which review may never be sought (granted that that universe is a dimimishing one, as Don Elliott's statistics seem to be telling us).

Before turning, then, to our narrower topic and asking how it might be examined, it might be useful to spend a moment or two on those older values or, perhaps, perspectives. In this respect, Cass' list of possible ways to define the benefits of review ${ }^{15}$ may relnind you of the triad of values often put forward for evaluating procedural choices. Years ago, writing of the hearing process, Roger Cramton identified them as accuracy, efficiency, and acceptability. ${ }^{16}$ The same three factors turn up in a shightly different fashion in the three models Jerry Mashaw invokes in Bureaucratic Justice: bureaucratic rationality, professionalism, and moral judgment. ${ }^{17}$ We want right outcomes, low cost, and satisfied custoiners-and it turns out we cannot inaximize all three at once. In both of those analyses, and in real life I submit to you, they turn out to be irreconcilable; we can hope for no better than a balance. And so to the extent one is undertaking a programmatic inquiry about the impact of close judicial scrutiny, one ought to do so in the context of a caution that judicial review itself can coinproinise inportant values.

I recall here the sense of loss in the move from Goldberg v. Kelly, ${ }^{18}$ with its focus (however difficult) on the individual circuinstances of the hitigants before that court, to the more general analysis of Mathews $v$. Eldridge. ${ }^{19}$ Judicial review, like hearings, serves a number of functions that aren't captured by talking about programmatic impact-providing some assurance of fairness to and recognizing the dignity and worth of individual participants; encouraging the sense of being heard; controlling the legality of particular governmental action. And these are matters we will clearly wish to keep in mind, even if we inagine the general question before us is being asked from some disembodied public-regarding point of view. "Are we the people (not particular litigants) better or worse off with strict judicial scrutiny?" will threaten the interests of particular litigants unless these interests are folded into the equations, and may do so even then.

15. Sunstein, On the Costs and Benefits of Aggressive Judicial Review of Agency Action, 1989 DUKE L.J. 522-25.

16. Cramton, A Comment on Trial-Type Hearings in Nuclear Power Plant Siting, 58 VA. L. REV. 585, 592-93 (1972).

17. J. Masháw, Bureaucratic Justice: Managing Soctal Security Disability ClaIMS 25-34 (1983).

18. 397 U.S. $254,262-66(1970)$.

19. 424 U.S. $319,335-49$ (1976). 
Looking at the matter this way points out a number of settings in which, even if we could not pretend to quantify, we would agree that the right outcome is for strict scrutiny: where constitutional claims are in the balance; where important personal interests are at stake-say, in the context of immigration proceedings; or where the issues are more judicial than admimistrative in provenance-say, the meaning of general law. The cases Cass discusses suggest possible additions to these categories. It is easy to agree, for example, that the courts should look hard at legal conclusions suggestimg a self-regarding agency expansion of jurisdiction; one is naturally concerned about the exercise of power. It is harder to agree, however, that a cost-benefit balance favors close scrutiny of priority ordering, or retrospective judicial assessments of agency decisions about what problems to address.

Here, I wonder if one must not distinguish rather sharply between the Benzene ${ }^{20}$ case and the Cotton Dust ${ }^{21}$ problein, as Cass would see them. The plurahty in Benzene could be regarded as having held only that the agency must have some priority system; the threshold showing of significant risk to worker health it found in the statute meant that the Secretary would have to justify her choice to proceed as well as her result, but did not suggest that the courts would attempt to assess precisely what the Secretary's priority ordering ought to have been once she had determined that that threshold had been passed. The decision about which risks to go after for the inoment and which to leave alone was left to her. ${ }^{22}$ The cost-benefit analysis Justice Powell would have required in Benzene, and that Cass apparently would have preferred in Cotton Dust, would put the Court in the position of supervising rather more precisely the cost-benefit assessinent or outcome of the particular rulenaking. This involves it much more deeply in the Secretary's decision of "what to do." Here especially, it seems to me, is where one gets to a comparative question. Why would one wish the courts to be involved in the close supervision of agency priority ordering rather than the political branches: Congress exercises its supervision through the appropriations or oversight process, and the President through powerful devices that have grown up in the same era as hard look review-the impact statement $^{23}$ and the regulatory agenda. ${ }^{24}$

20. Industrial Union Dep't v. American Petroleum Inst., 448 U.S. 607 (1980).

21. American Textile Mfrs. Inst. v. Donovan, 452 U.S. 490, 508-09 (1981).

22. Industrial Union Dep't, 448 U.S. at 639-46.

23. Executive Order No. 12,291, 3 C.F.R. 127, reprinted in 5 U.S.C. $\S 601$ app. at 431-34 (1982).

24. Executive Order No. 12,498, 3 C.F.R. 323 (1986), reprinted in 5 U.S.C.A. $\S 601$ app. at 315-16 (West Supp. 1989). 
We administrative lawyers have not, in fact, tended to think in a disciplined way about political controls as a forn of oversight that may be superior in some settings to judicial review. Yet a nionient's thought will suggest that, for all its well-known risks, this form of oversight also offers, in some settings, decided advantages: its operation in real time, as the agency is acting, rather than years after the event; its openness to compromise and accommodation; its tie to political accountability; its possible responsiveness to the polymorphic and contingent character of many rulemaking disputes.

All this may lead us to an interesting observation about the domain of the "hard look" issue as it is usually understood. Hard look involves ruleinaking proceedings in which the outcomes may have high social consequences (people may have to spend a lot of inoney; businesses may be undone) but in which participatory values generally and the review issue in particular have no individualistic focus. These polymorphic disputes, the characteristic doinain of the hard look rule, are precisely those about which Holmes reinarked in the Bi-Metallic case that there is no individual right to be heard, that the citizens" "rights are protected in the only way that they can be in a complex society, by their [political] power, immediate or remote, over those who make the rule." 25 The clain for participation and for an intensity of review are uniquely to serve public values, and that might suggest more difficulty in reaching the net benefit outcome. A court is an odd place, as Martin Shapiro recently pointed out in his Richard B. Russell lectures at Georgia, to be looking for large scale political controls; its personnel and its procedures are ill suited to those tasks. ${ }^{26}$

By way of suggesting a comparison between political and judicial mechanisms for review, I want to tell you what to me is a cautionary story about the progenitor of hard look, Citizens to Preserve Overton Park, Inc. v. Volpe. ${ }^{27}$ We all know that case as the progenitor of hard look review, because of Justice Marshall's lengthy discussion of what the role of a court in judicial review ought to be. We tend to lose sight of what, from the hitigant's perspective, was the priniary issue presented to the Court: how the Secretary of Transportation should have interpreted two parallel federal statutes that required him to assure that park values were taken into account in funding federal highways. ${ }^{28}$ The precise issue

25. Bi-Metallic Inv. Co. v. State Bd. of Equalization, 239 U.S. 441, 445 (1915).

26. See M. SHAPIRo, supra note 9, at 161-64.

27. 401 U.S. 402 (1971).

28. Department of Transportation Act of 1966, Pub. L. No. 89-670 § 4(f), 80 Stat. 931, 934 (codified as amended at 49 U.S.C. $\$ 1653(\mathrm{f})$ (1982)) (use parkland only if "no feasible and prudent alternative" and "program includes all possible planning to minimize harm"); Federal Aid-Highway 
was the fate of 26 acres of Overton Park, a beautiful 342-acre park in downtown Memphis, that were needed to build an interstate highway through the city. Most of the road was already in place, but the park segment remained unfinished awaiting final approval from federal authorities. ${ }^{29}$ It appears that, taking provisions in this statute and others referring to local hearings of a political character as his cue, the Secretary had gone to the City Council of Memphis and told them to make their decision without taking cost into account as a factor. ${ }^{30}$ Since the

Act of 1968 , Pub. L. No. 90-495, 82 Stat. $815,823-24$ (1968) (codified as amended at 23 U.S.C. $\$ 138$ (1982)) (same).

29. The issue had been on the table since 1955, and the route through the park first won (provisional) federal approval from the Bureau of Roads in 1956-at that point, it is fair to say, on a basis that called attention to the lower cost and reduced dislocations that would result from building through the park rather than around its well-settled perimeter. Like Westway more recently in New York City, and other inner-city expressways, the route remained a hotly debated local issue for more than a decade after. The enactment of amendments to the relevant federal statutes in 1968 introduced constraints on the use of parkland, and required reconsideration. Compare Federal-Aid Highway Act of 1966 Pub. L. No. 89 574, 80 Stat. 766, 771 (1966) with Pub. L. No. 90-495, 82 Stat. at 823-24.

30. This account draws on Federal Highway Administrator Bridwell's testimony to a Senate Hearing before the Subcommittee on Roads, May 18, 1968, relied on by the Sixth Circuit in the opinion later reversed by the Supreme Court:

We went to the city council of Memphis and we said, "Yes, there are alternatives. We won't even give you any information on what the alternatives cost in dollars because we don't want that to be a factor in your recommendation of which line to choose. Rather, we would like you to focus upon the conflicting set of community values that are inherent in this kind of a situation."

Citizens to Preserve Overton Park, Inc. v. Volpe, 432 F.2d 1307, 1313 (6th Cir. 1970) rev'd, 401 U.S. 402 (1971). In addition to section 4(f)'s reference to local determination of the possible significance of parkland for the purposes of that section, 49 U.S.C. $\$ 1653(\mathrm{f})$, another provision generally bearing on issues of road location explicitly required a state hearing process in localities to be affected by proposed projects. 23 U.S.C. $\$ 128$ (1982). Its evident purpose, elaborated in applicable federal regulations, was to ensure a local forum for the resolution of development issues that would be educated about and responsive to environmental as well as developmental concerns. See generally Gray, Cases and Materials on ENVIronmental Law 913-914 (1970). Much of the litigation prior to the Court's decision had been concerned with whether this hearing met that requirement.

An author making the transition from oral discussion gadfly to writer-for-the-ages is obliged to admit that the full tale of Overton Park is a good bit more complex than his oral remarks may suggest. There were those who believed-and with some support in the record-that Highway Administrator Bridwell's account was self-serving if not deceitful. There appear to have been convenient gaps in the hearing records over the years, that mysteriously coincided with opponents' presentations. See Death Row, Audubon, Jan. 1970, 120, 121; but see Overton Park, 432 F.2d at 1313 " In our opinion, the testimony of Mr. Bridwell is further evidence that the Secretary complied with the statute"). After the February 14, 1968 public meeting, the City Council had approved a resolution stating that it "prefers that the Expressway . . . be not routed in its present proposed location but . . . another," indieating one which it would approve "if no better route can be obtained." Appendix to Briefs at 23 Overton Park, 401 U.S. 402 (1971) (No. 1066). In April, Administrator Bridwell met again with the City Council-this time in private-and it changed its tune, adopting a resolution flnding the park route to be the "feasible and prudent location." Id. at 26. Cf. Death Row, supra, at 121 ("Bridwell proceeded to ram I-40 down the City Council's throats") with 3 PARKS \& RECREATION 62 (Sept. 1968) (Bridwell merely "urged the councilmen to decide what they 
federal government was to provide $90 \%$ of the cost of the roadway wherever it was located, he said, they should disregard that factor and take special account of parkland values. This armed the already active, local political process. This issue was before the City Council for weeks, was spread across the pages of the Memphis newspapers, and eventually resulted in a settlement. The State of Tennessee paid what amounted to condemnation money to the City of Memphis for the 26 acres of Overton Park, and-pursuant to an ordinance enacted in this connection-the City of Memplis used the money to buy several liundred acres of replacement parkland, one indication that it had indeed taken special care to preserve parkland values. The Secretary released the $90 \%$ federal funding.

Since the Secretary wrote no opinion, only his course of conduct suggests that he had interpreted the statute's language about assuring the protection of parkland values as embracing this political approach. Yet this was an available interpretation of the statute, and the Court acknowledges in its opinion tliat "[t]he legislative history . . . is ambiguous." ${ }^{31}$ It rejected that approach to the statute, however, in favor of one in which the courts were to take a hard look to assure that parkland values had been protected. A legal process, a judicial process, was used rather than a political process because in the Court's judgment any other approacli would risk tliat parkland values would be submerged rather than be assigued the "paramount importance" 32 it had concluded the statute required.

Similar developments were occurring at tlie same time in the context of environmental control. The National Environmental Policy Act easily could have been understood as a statute intended to arm a bureaucratic device for political enforcement. ${ }^{33}$ It was not so understood, and became

wanted to do about the expressway," indicating that with the Council's support, he could "defend the Overton Park route in court.").

This is not the forum to tell the whole story, more complex than hinted at here; that is a project long on my to-do list. The problem in knowing just what happened in Memphis points out a diffculty in relying on political controls, undoubtedly present. Yet the Administrator's course in dealing with the Memphis City Council and exposing it to political heat, whatever its decision, was clearly within the possibilities opened by the language of sections $4(f)$ and 138, "an ambiguous compromise between highway advocates and environmentalists." R. STEWART \& J. KRIER, ENVIRONMENTAL LAW AND POLICY 679 (2d ed. 1978); see Overton Park, 401 U.S. at 412 n.29 ("The legislative history . . . is ambiguous."); Note, The Supreme Court, 1970 Term, 85 HARv. L. REv. 324-25 (1971). And such disagreements are often worked out in the political marketplace; the question remains one of balancing the relative advantages and risks of alternative approaches.

31. Overton Park, 401 U.S. at 412 n.29.

32. Id. at $412-13$.

33. The Supreme Court's interpretation of NEPA this spring in Robertson v. Methow Valley Citizens Council, 109 S. Ct. 1835, 1847 (1989), announced after these remarks were delivered, suggests a more political understanding of the statute. The Court in that case refused to understand 
the occasion for widespread judicial enforcement.

Particularly in the context of the fiscal challenge that we all face, wishing to regulate to some extent and knowing that we have not got very much money for those who are going to do it, we need to be reconsidering the wisdom of these choices. Finding a purpose to enforce political controls in the statutes underlying Overton Park would have effectively transferred the responsibihty for decision from bureaucrats in Washington to a politically responsible municipal council in Memphis, Tennessee, while making clear that parkland values were central. The council members were going to pay with their next terins if they made the wrong choice in terins of the local values of the people of Meinphis. While the political process hardly assured perfection-risking, for example, preference for racially discrete small parks over a city-wide magnet-it evidently fostered the values of negotiation and compromise.

Judicial enforcement, by contrast, was bipolar, produced without regard for the values of potitics. Whatever else was the case for Citizens to Preserve Overton Park, Inc., the chief cost confronting the plaiutiff in deciding to sue-however public spirited its members may have been by their own hights-was the price of their own lawyers. It was, as was earlier remarked, rather cheap for them to sue. The monkey wrench was available. ${ }^{34}$ One might be reassured if one knew that the inonkey wrench would always be exercised by public-spirited groups like Citizens to Preserve Overton Park, Inc. but it appears that the largest portion of law-

NEPA as commanding action as well as analysis; the fact of the analysis might arm a political response, or change the environmeut in which it would occur, but the courts had no role to play in enforcing agency responses to NEPA analyses, oncc they had been appropriately made.

34. Again, the desirable simplicity of oral remarks conceals a more complex reality. Two issues were presented in the case-whether the park route could be used at all; and, if it was to be used, whether all appropriate steps had beeu taken to secure parkland values to the maximum feasible degree. The Department had decided the first question as early as 1956 , and iu any event no later than the period following Administrator Bridwell's trips to Memphis in the spring of 1968; the second was not decided until the fall of the following year.

Give and take on design decisions (Shall the roadway be on the surface? In a cut depressed beneath it? In a tunnel under the park, with appropriate ventilation devices?) is perhaps more readily imagined, even for a party such as Citizens to Preserve Overton Park. Here, too, one can argue that the presence of an auchor to wiudward-citizens' groups who will sue if the Secretary is too forthcoming in her dealings with developers-will stiffen the Secretary's resolve and thus produce better outcomes in a process of compromise and accommodation. In the lower courts, the litigation appears to have been as much concerned with the adequacy of the Secretary's design determinations as with the legality of having the road in the park at ali. See Citizens to Preserve Overton Park, Inc., v. Volpe, 309 F. Supp. 1189, 1195 (D. Tenn.), aff'd, 432 F.2d 1307 (6th Cir. 1970), rev'd, 401 U.S. 402 (1971); Citizens to Preserve Overton Park, Inc. v. Volpe, 335 F. Supp. 873, 883-85 (D. Tenn 1972). Indeed, clearing of the projected roadway up to the very border of the park was well under way by 1969, Overton Park, 432 F.2d at 1312-13, and the absence of litigation to stop it suggests an understanding that the true stakes lay in how, not whether, the roadway would be built. In this respect, the Court's focus on the first question may have come as something of a shock. 
suits challenging agency action brought in the D.C. Circuit (and I imagine elsewhere) is brought by corporations and not the others. So this is, I believe, a cautionary tale.

One political alternative to hard look, against which comparative assessments perhaps need to be freshly made, lies in the oversight of agency rulemaking by OMB's Office of Information and Regulatory Analysis (OIRA) under Executive Order Nos. 12498 and 12291. ${ }^{35}$ To what extent is the work that we might have thought was being done by hard look review now being done by the President's staff-however imperfectly, however pohtically-in that setting where we have long thought, as Holmes said, that the citizens' rights are primarily to be protected by their political power over those who make the rules and not by other processes. ${ }^{36}$

It would not be hard to describe the OIRA process as a Presidential substitute for hard look review. Whatever else this process does-and one understands that for some it is arm-twisting, for others necessary coordmation ${ }^{37}$-it forces attention to facts and policy choices just as hard look review may.

While the presidential review mechanisms present political hazards hard look review may not, they also have decided advantages. The President's staff is in a better position than a court to get (and has the incentive to get) the "big picture"- to understand how this enterprise fits with others, to formulate and even enforce a sense of priority in governmental action. Judicial review is necessarily atomistic, irresponsible, uninformed by such concerns and perspectives. Moreover, if increasingly we have to worry about the cost of regulating as well as the cost of regulation-if, that is, agencies will have to stretch their regulatory dollars in a budgetdeficit-conscious environment-presidential controls are more likely than judicial ones to accommodate those realities. Their resource demands can be modified more flexibly as they become apparent, or as it appears desired patterns of analysis have been adopted by the agencies themselves. Focused management, in general, seems more likely than dispersed management to produce cost-effective pursuit of the public interest, within whatever budgetary constraints are imposed. Once we have taken the public rather than the private law posture toward the

35. Executive Order No. 12,498, 3 C.F.R. 323 (1986), reprinted in 5 U.S.C. $§ 601$ app. at 315 16 (West Supp. 1989); Executive Order No. 12,291, 3 C.F.R. 127, reprinted in 5 U.S.C. $\S 601$ app. at 431-34 (1982).

36. See supra note 25 and accompanying text.

37. The recent literature is collected in Bruff, Presidential Management of Agency Rulemaking, 57 Geo. WASH. L. Rev. 533 (1989); see also National Acad. of Pub. Admin., Presidential Management of Rulemaking in Regulatory Agencies (1987). 
possible value of review, valuing systematic more than individual justice issues, the question may be gaining some sense of an ideal balance in regulation. If we have tradeoffs between quality and quantity, we will need to learn how to value one as against the other. Close scrutiny judicial review, concerned with just this proceeding, cannot readily ask such questions.

In the best of worlds-that is, in a world where one could rely on the courts for an apohtical objectivity in sharp contrast to the contributions of President and Congress-one would still have had the difficult task of evaluating the shadow effects as well as the direct effects of close scrutiny, of evaluating its inpact on adıninistrative proceedings without regard to whether they are actually reviewed in court. Here we return to the argument between Bill Pedersen, ${ }^{38}$ say, and Shep Melnick ${ }^{39}$ about whether that impact is helpful, or randonı and perhaps paralyzing. Recent scholarship is tending to the latter assessment; in addition to the studies already mentioned, you will want to see John Mendeloff's Dilemma of Toxic Substance Regulation, ${ }^{40}$ a study of the relation between over-regulation and under-regulation at OSHA, and the forthcoining study by Jerry Mashaw and David Harfst, The Freedom Machine. ${ }^{41}$ Mashaw and Harfst show, in the particular context of the National Traffic and Motor Vehicle Safety Act, how hard look review appears to have contributed to a paralysis of the rulemaking process. The resulting practice of defensive law, in the context of rulemaking, produces outputs of such intricacy and detail as to swallow the possibility of significant action; hence, their stunning finding that NHTSA hasn't begun work on a niajor new rule since the administration of Gerald Ford.

One needs to acknowledge that rulemaking paralysis is hardly only the courts' fault. Indecision in Congress and changing admimistrations has had a lot to do with it. Yet there is truth also in two perspectives the Supreme Court was able to gain in the Vermont Yankee case: first, that review expectations can lead to a defensive practice of law that disserves the agency's general program; ${ }^{42}$ second, that for coniplex proceedings, close scrutiny inevitably focuses on only one or a few of inany issues, and thus distorts agency process-it may demand a level of perfection in practice that no one could justify in theory. ${ }^{43}$ When the Departnient of Transportation's initial air-bag rule-the result of extended proceedings

38. See supra note 6 and accompanying text.

39. See supra note 10 and accompanying text.

40. J. Mendeloff, The Dilemma of Toxic Substance Regulation: How OverreguLATION CAUSES UNDERREGUlation AT OSHA 115-22 (1988)

41. See supra note 3 and accompanying text.

42. Vermont Yankee Nuclear Power Corp. v. NRDC, 435 U.S. 519, 547 (1978).

43. Id. at $553-54,558$. 
and embodying countless complex judgments-could be stymied for failure to develop a sufficiently stiff-necked testing dummy, ${ }^{44}$ the agency learned a hard lesson about the exactitude to which it might be held.

The risks of this sort of hard look are magnified by the realization of how himited are the realistic possibilities for the Supreme Court's discipline of the federal judicial system. An article I published in the fall of $1987^{45}$ suggested that a federal court of appeals judge would not expect her opinions to be reviewed by the Court more than two or three times a decade-hardly a significant prospect for control. The result is to make it much harder to rely on the judicial outcome as mvolving any necessary precision or coherence. The President may reasonably claim that balance and cohesion will more likely result from his processes.

All this may suggest that in writing about judicial review from the public rights perspective, too, the relevant question is "close scrutiny of what?" And one must ask too, for what ends-that is, with what image of the administrative system and its ends in view. I find it hard to disagree with the conclusion of Martin Shapiro's Russell lectures. Coming to grips with a world of statutes that do not in fact have fixed meanings, of complex teclinological problems that do not have demonstrably correct answers, means that we can expect little more from agencies than careful deliberation and prudence-and the role of the courts in this political context should be no more ambitious than to encourage those qualities. If one could capture in a formula the level and object of judicial scrutiny that would arm the forces of reason within the agencies without encouraging defensive excess, that would be our goal. It is, as it always has been, a matter of the judges being aware of their own limits at the same time as they set limits for others. Shapiro's closing words seem apt enough for me:

[W] know that judges are really no more prudent than the rest of us. So long as we let the judges know that we know that, they are unlikely to get overambitious about substituting their prudence for that of others more directly subject to democratic control. ${ }^{46}$

44. Chrysler Corp. v. Department of Transp., 472 F.2d 659 (6th Cir. 1972); see also Love v. Thomas, 858 F.2d 1347 (9th Cir. 1988).

45. Strauss, One Hundred Fifty Cases per Year: Some Implications of the Supreme Court's Limited Resources for Judicial Review of Agency Action, 87 CoLUM. L. REv. 1093, 1098-99 (1987).

46. M. SHAPIRO, supra note 9, at 173. 